\title{
Fermentation profile and chemical composition of cassava root silage
}

\author{
Juliana Schuch PITIRINI, Rosana Ingrid Ribeiro dos SANTOS, Francy Manoely da Silva LIMA, Ilano Silva \\ Braga do NASCIMENTO, Jehmison de Oliveira BARRADAS, Cristian FATURI, Aníbal Coutinho do RÊGO, \\ Thiago Carvalho da SILVA* (1) \\ Universidade Federal Rural da Amazônia, Av. Tancredo Neves 2501, Terra Firme, CEP 66077-830, Belém, Pará, Brazil \\ * Corresponding author: thiago.silva@ufra.edu.br; D https://orcid.org/0000-0002-7823-3950
}

\begin{abstract}
The use of cassava root silage for animal feeding is a suitable option for farmers who grow cassava as an alternative product and for cattle ranchers who have to deal with high prices of corn. Our objective was to determine the effects of cassava genotypes and the correction of soil acidity on the microbial population, fermentation characteristics, chemical composition, aerobic stability and losses of cassava root silage. We used a $2 \times 3$ factorial design in completely randomized blocks, with four replications. We evaluated two cassava genotypes (Caeté and Manteiguinha) and three methods of soil acidity correction (lime, gypsum, and lime+gypsum). The roots were harvested 11 months after planting, ensiled in PVC silos, and stored for 45 days. No interaction was observed between genotypes and soil acidity correction for any of the evaluated parameters. The silage of Caeté genotype showed the highest concentration of dry matter $\left(421 \mathrm{~g} \mathrm{~kg}^{-1}\right.$ fresh matter) and non-fibrous carbohydrates (893 $\mathrm{g} \mathrm{kg}^{-1}$ dry matter), and the lowest concentrations of neutral detergent fiber $\left(37.1 \mathrm{~g} \mathrm{~kg}^{-1}\right.$ dry matter) . No significant differences were observed among treatments for lactic acid bacteria, yeast and mold counts in silages. Both genotypes resulted in silages with an adequate fermentation profile and considerably high aerobic stability, but with high effluent loss. The Caeté genotype showed to be potentially better for silage production due to its higher dry matter recovery. Due to the high level of effluent loss, it is recommended to test the effect of a moisture-absorbing additive during the ensiling process of these cassava roots.
\end{abstract}

KEYWORDS: ensiling, feed conservation, fermentation, Manihot esculanta, sustainable crops

\section{Efeito do genótipo e da correção de acidez do solo sobre o perfil fermentativo e a composição química da silagem de raiz de mandioca}

\section{RESUMO}

O uso da silagem de raiz de mandioca na alimentação animal representa uma opção viável tanto para os produtores que cultivam mandioca (visando ter um produto para comercializaçáo alternativa), quanto para os pecuaristas que compram milho a preços elevados. Assim, objetivou-se determinar o efeito de variedades e da correçáo da acidez do solo sobre as populaçóes microbianas, características fermentativas, composição química, estabilidade aeróbia e perdas de silagens de raízes de mandioca. O experimento foi conduzido em delineamento em blocos casualizados, em arranjo fatorial $2 \times 3$ com quatro repetiçóes. Foram avaliados dois genótipos de mandioca (Caeté e Manteiguinha) e três tipos de correção de acidez do solo (calagem, gessagem e calagem+gessagem). Após 11 meses, as raízes foram colhidas, trituradas e ensiladas em silos do tipo PVC, onde permaneceram por 45 dias. Não observamos efeito de interação entre genótipos e correção do solo para os parâmetros testados. As silagens do genótipo Caeté apresentaram as maiores concentraçóes de matéria seca (421 g kg-1 matéria fresca) e carboidratos não fibrosos (893 $\mathrm{g} \mathrm{kg}^{-1}$ matéria seca), e menores de fibra em detergente neutro ( $37.1 \mathrm{~g} \mathrm{~kg}^{-1}$ matéria seca). Não houve diferenças significativas entre tratamentos para bactérias ácido láticas, leveduras e mofos nas silagens. Ambos os genótipos resultaram em silagens com perfil de fermentação adequado e estabilidade aeróbia consideravelmente elevada, mas com elevadas perdas de efluentes. O genótipo Caeté apresentou condiçóes potencialmente melhores para produçáo de silagem devido a sua maior recuperaçáo de matéria seca. Devido à alta perda de efluente, recomendamos testar o efeito da adição de um aditivo absorvente de umidade durante o processo de ensilagem dessas raízes de mandioca.

PALAVRAS-CHAVE: conservação de alimentos, culturas sustentáveis, ensilagem, fermentação, Manihot esculenta 


\section{INTRODUCTION}

Cassava (Manihot esculenta Crantz) is a largely used crop in tropical regions of the world and Brazil is the fourth largest producer of cassava in the world (FAO 2020), with a total production of approximately 19 millions tons in 2020 (IBGE 2021). Almost $40 \%$ of the cassava production in Brazil comes from the northern Amazonian region, and Pará state is the largest producer in the country (IBGE 2021).

Cassava is used for human and animal feeding and is processed for several industrial purposes. In the Amazon region, cassava is a staple food for indigenous and nonindigenous populations, and is the main income source of smallholder farmers, which leads to the preservation of a range of genotypes cultivated in the region (Elias et al. 2004). The majority of cassava roots produced in the Amazon region is used to produce cassava flour, and also to produce starch, ethanol, alcoholic beverages and animal feed (Ajibola et al. 2012; Supapong et al. 2019; Coelho et al. 2020).

The diversification of uses of cassava roots is an important strategy to assure the maintenance and income of smallholder farmers (Santos and Santana 2012), because the market value of cassava flour is considerably variable (CEPEA 2020). In this context, the use of cassava roots as a substitute for corn in animal feeding is an interesting strategy, as corn is an expensive component of feed (Sudarman et al. 2016; Saree et al. 2017). The ensiling of cassava roots is an option to preserve this product through a fermentation process and to use it in diets for both ruminant and non-ruminant animals, such as cattle and swine, respectively (Loc et al. 1997; Vieira et al. 2017).

Cassava root silage preserves the nutritive value of the fresh product and decreases its concentration of hydrocianidric acid, which is present in significant amounts in the roots (Loc et al. 1997; Chisté et al. 2010). Despite its high potential, there are few studies on cassava root silage, specially in Brazil (Loc et al. 1997; Silva et al. 2010; Vieira et al. 2017). The existing studies have not evaluated the characteristics of cassava root silage, which is the first step to evaluate the effectiveness of the ensiling process and the preservation of the nutritive value of the product. In addition, the fermentation process can be affected by genetic characteristics of ensiled cassava, fertilization and management of the crop. Soil acidity can also affect silage fermentation, as Amazonian soils have low natural fertility due to the presence of acids, aluminum toxicity and low base saturation (Soares et al. 2005). Soil-acidity correction measures such as liming are able to promote a better extraction of nutrients from the soil (Raij 1991), which can translate into larger substrates in the plant that will be available in the fermentation process.

Thus, our objective was to evaluate the fermentation characteristics and the chemical composition of cassava root silages produced with two genotypes cultivated with different soil acidity correctives.

\section{MATERIAL AND METHODS}

\section{Study site}

The experiment was conducted at Universidade Federal Rural da Amazônia - UFRA, in Belém, Pará state, Brazil $\left(1^{\circ} 27^{\prime} 07^{\prime \prime} \mathrm{S}, 48^{\circ} 26^{\prime} 13^{\prime \prime} \mathrm{W}\right)$, at an altitude of approximately 11 $\mathrm{m}$. The climate in the region is classified as Af (tropical humid) according to the Köppen classification system (Köppen 1918), is characterized by abundant rainfall throughout the year, a main rainy season between December and May, and a low rainy season from June to November, with average annual temperature of $26^{\circ} \mathrm{C}$, and average annual precipitation of 2,774.3 mm (Alvares et al. 2014). The soil of the experimental area was classified as a dystrophic Yellow Latosol (Oxisol). (Santos, et al.; 2013). Five soil samples were randomly taken from a $0-20-\mathrm{cm}$ depth within the experimental blocks, from which a composite sample was formed and analyzed for chemical properties in the Soil Chemistry Laboratory of UFRA (Table 1).

\section{Procedures and experimental design}

The experimental design was in completely randomized blocks, in a $2 \times 3$ factorial design with four replications (total of 24 experimental units). The studied factors were two cassava genotypes (Caeté and Manteiguinha) and three methods of soil-acidity correction [lime (L), gypsum $(\mathrm{G})$, and $\mathrm{L}+\mathrm{G}$ ].

Based on the characteristics of the soil (Table 1), the amount of lime applied was $1.22 \mathrm{tha}^{-1}(\mathrm{PRNT}=100 \%)$, using the exchangeable aluminum neutralization method (Cravo $e t$ al. 2016). Agricultural gypsum was applied at a dose of $1.2 \mathrm{t}$ $\mathrm{ha}^{1}$, following the recommendation for annual crops for yellow oxisoil type by Sousa et al. (2007). The same amounts were used in the combined lime+gypsum treatment. Soil-acidity correctors were applied 20 days before planting the cassava stems (seeds). Fertilization followed the recommendation

Table 1. Chemical composition of Yellow Latosol (Oxisol) samples collected at the campus of Universidade Federal Rural da Amazônia, Belém, Pará state, Brazil before the application of acidity correctives.

\begin{tabular}{|c|c|c|c|c|c|c|c|c|}
\hline $\begin{array}{l}\text { Depth } \\
(\mathrm{cm})\end{array}$ & $\begin{array}{c}\mathrm{pH} \\
\left(\mathrm{H}_{2} \mathrm{O}\right)\end{array}$ & $\begin{array}{l}\mathrm{N} \\
(\%)\end{array}$ & $\begin{array}{c}P^{1} \\
\left(\mathrm{mg} \mathrm{dm}^{-3}\right) \\
\end{array}$ & $\begin{array}{c}\mathrm{K}^{+} \\
\left(\mathrm{mg} \mathrm{dm}{ }^{-3}\right) \\
\end{array}$ & $\begin{array}{c}\mathrm{Na}^{+} \\
\left(\mathrm{mg} \mathrm{dm}^{-3}\right)\end{array}$ & $\begin{array}{c}\mathrm{Ca}^{2+} \\
\left(\mathrm{cmol}_{c} \mathrm{dm}^{-3}\right)\end{array}$ & $\begin{array}{c}\mathrm{Mg}^{2+} \\
\left(\mathrm{cmol}_{c} \mathrm{dm}^{-3}\right)\end{array}$ & $\begin{array}{c}\mathrm{Al}^{3+} \\
\left(\mathrm{cmol}_{c} \mathrm{dm}^{-3}\right)\end{array}$ \\
\hline $0-20$ & 4.6 & 0.05 & 6 & 22 & 14 & 0.3 & 0.2 & 1.4 \\
\hline
\end{tabular}

$\mathrm{N}=$ nitrogen; $\mathrm{P}=$ phosphorus (Mehlich extraction); $\mathrm{K}^{+}=$potassium (Mehlich extraction); $\mathrm{Na}^{+}=$sodium (Mehlich extraction); $\mathrm{Ca}^{2+}=$ calcium ( $\mathrm{KCl} 1.00 \mathrm{~mol} \mathrm{~L}^{-1}$ extraction); $\mathrm{Mg}^{2+}=$ manganesium ( $\mathrm{KCl} 1.00 \mathrm{~mol} \mathrm{~L}^{-1}$ extraction); $\mathrm{Al}^{3+}=$ aluminium (calcium acetate $0.05 \mathrm{~mol} \mathrm{~L}^{-1}$ extraction). 
for the state of Pará by Cravo et al. (2010). As nitrogen, phosphorus, potassium and micronutrient sources we used urea, triple superphosphate (TSP), potassium chloride (KCL), and FTE-BR12, respectively.

The cassava stems were cultivated with $1 \mathrm{~m}$ between rows and $0.5 \mathrm{~m}$ between plants, with five plants per plot and four replicates (plots) per treatment. Due to logistics, the cassava was harvested (and the material ensiled) over four weeks. Each week a plot of each treatment was harvested, and so the week of harvest and ensiling was used as the blocking criterium. Eleven months after planting, cassava roots were harvested. The blocking dates were 19 Jan, 20 Jan, 27 Jan and 30 Jan 2019. Each block contained six plots, one of each treatment. The roots were separated from the foliage and chopped in a stationary forage chopper (TRF 400, Trapp, Brazil) regulated to obtain a particle of approximately $2 \mathrm{~cm}$. A sample of 500 $\mathrm{g}$ of the chopped cassava from each plot was separated for chemical characterization. Approximately $2.85 \mathrm{~kg}$ of chopped roots were placed in cylindrical PVC silos (volume $=0.0024$ $\mathrm{m}^{3}$; packing density $=1.186 \pm 131 \mathrm{~kg} \mathrm{~m}^{-3}$ fresh basis), containing $1.5 \mathrm{~kg}$ of dry sand covered with cotton cloth to absorb the effluent produced for later calculation of effluent loss. One silo was produced for each plot, totalling four silos per treatment. Each silo (experimental unit) was sealed, weighed and stored at the Animal Nutrition Laboratory of UFRA at room temperature $\left(28.1 \pm 0.9^{\circ} \mathrm{C}\right)$ for 45 days.

At the end of the storage period, the silos were again weighed to quantify the dry matter recovery (DMR). The silos were opened, and the deteriorated portion of the silage (with visible mold) was removed before sampling. The empty silos and the sand were weighed for the calculation of the effluent loss (EL). The DMR and EL were calculated using the equations proposed by Jobim et al. (2007). We collected a sample of $500 \mathrm{~g}$ of the silage from each experimental unit for laboratory analyses.

The fresh silage samples were transferred to 5 -L plastic buckets, which were stored at constant temperature of 25 $\pm 0.6{ }^{\circ} \mathrm{C}$ for seven days (168 hours). During this period, ambient temperature and silage temperature was recorded every four hours, the latter with a thermometer (Tp101, Matsuri, China) inserted into the geometric center of the silage mass. Aerobic stability (AS) was defined as the number of hours the temperature of the silage remained stable before rising more than $2{ }^{\circ} \mathrm{C}$ above the ambient temperature (O'Kiely 1993). We also determined the time to reach the maximum temperature (HMaxT), maximum temperature $(\mathrm{MaxT})$, minimum temperature (MinT), and temperature amplitude (AMP) (the difference between the maximum and minimum temperatures) of the fermentation process.

\section{Microbial population and fermentation profile}

The evaluation of microbial populations in the silage was carried out at the Animal Nutrition Laboratory of UFRA. For each replicate, an aqueous extract with $25 \mathrm{~g}$ of silage and $225 \mathrm{~mL}$ of sterile peptone water was prepared, which was homogenized manually for $3 \mathrm{~min}$. Serial dilutions from $10^{-3}$ to $10^{-8}$ were prepared and plated on Petri dishes using the pour plate technique with Potato Dextrose Agar culture medium (Sigma-Aldrich Brasil Ltda) for yeasts and molds, and MRS AGAR (Sigma-Aldrich Brasil Ltda) for lactic acid bacteria (LAB). Plates were incubated in a germination chamber (BIOFOCO-BF2 CGFP 275) at $26^{\circ} \mathrm{C}$ for three and five days for yeasts and molds, respectively, and the colony forming units (CFU) of each microorganism were identified based on their macromorphological characteristics and counted (Knop 2011). The plates for $\mathrm{LAB}$ were incubated at $35^{\circ} \mathrm{C}$ for three days. After microbial analysis, we measured the $\mathrm{pH}$ of the aqueous extract using an electrode (Tekna T-1000).

\section{Chemical composition}

The determination of the chemical composition of the harvested chopped roots (Table 2) and the silage were carried out at the Animal Nutrition Laboratory of UFRA. The samples were weighed and dried in a forced air oven $\left(55^{\circ} \mathrm{C}\right.$ for 72 h) and then ground in a Willey knife mill (STAR-FT-80/2) with a screen size of $1 \mathrm{~mm}$. The analysis of the concentration of dry matter (DM) (method 934.01), organic matter (OM) (method 923.03), and crude protein (CP) (method 978.04) followed the official methods of AOAC (1990).

Table 2. Chemical composition of the roots of two cassava (Manihot esculenta) genotypes planted in experimental plots at the campus of Universidade Federal Rural da Amazônia, Belém (Pará state, Brazil) using three types of soil acidity correction. Values are the mean of four in natura samples (before ensiling).

\begin{tabular}{|c|c|c|c|c|c|c|c|}
\hline \multirow{3}{*}{ Parameter } & \multicolumn{6}{|c|}{ Genotype } & \multirow{3}{*}{ SEM } \\
\hline & \multicolumn{3}{|c|}{ Caeté } & \multicolumn{3}{|c|}{ Manteiguinha } & \\
\hline & $\mathrm{L}$ & G & $L+G$ & $\mathrm{~L}$ & G & $L+G$ & \\
\hline Dry matter ( $\left.\mathrm{g} \mathrm{kg}^{-1} \mathrm{FM}\right)$ & 412.0 & 398.0 & 399.0 & 356.0 & 358.0 & 374.0 & 9.59 \\
\hline Organic matter ( $\left.\mathrm{g} \mathrm{kg}^{-1} \mathrm{DM}\right)$ & 959.0 & 950.1 & 939.9 & 950.7 & 947.2 & 946.6 & 2.56 \\
\hline Crude protein ( $\left.\mathrm{g} \mathrm{kg}^{-1} \mathrm{DM}\right)$ & 24.7 & 24.0 & 22.6 & 23.1 & 22.4 & 22.6 & 0.38 \\
\hline Ether extract ( $\left.\mathrm{g} \mathrm{kg}^{-1} \mathrm{DM}\right)$ & 2.9 & 3.1 & 4.4 & 3.2 & 3.1 & 3.4 & 0.22 \\
\hline Neutral detergent fiber ( $\left.\mathrm{g} \mathrm{kg}^{-1} \mathrm{DM}\right)$ & 41.6 & 53.3 & 55.4 & 59.9 & 59.7 & 58.7 & 2.84 \\
\hline Non fibrous carbohydrates ( $\left.\mathrm{g} \mathrm{kg}^{-1} \mathrm{DM}\right)$ & 889.8 & 869.7 & 857.4 & 864.5 & 861.0 & 861.9 & 4.78 \\
\hline
\end{tabular}

$\mathrm{FM}=$ fresh matter; $\mathrm{DM}=$ dry matter $\mathrm{L}=$ lime; $\mathrm{G}=$ gypsum; $\mathrm{L}+\mathrm{G}=$ lime+gypsum; $\mathrm{SEM}=$ standard error of the mean. 
The concentration of ether extract (EE) was determined in a fat extractor (Model: XT10- Ankom ${ }^{\circ}$; Method: Am-5-04) according to AOCS (2009). The concentration of neutral detergent fiber (NDF) was determined in accordance with method 973.18 of AOAC (1990) with the use of alpha amylase and without sodium sulfide. The concentration of non-fibrous carbohydrates (NFC) was calculated according to Detmann and Valadares Filho (2010), and ammonia nitrogen $\left(\mathrm{NH}_{3}-\mathrm{N}\right)$ according method 941.04 of AOAC (1990).

\section{Statistical analyses}

All variables submitted to statistical tests were analyzed through the Shapiro-Wilk test for checking normality and through the Levene test for homogeneity of variance. Data from microbial populations were transformed to $\log _{10}$ for normalization. All variables were submitted to analysis of variance, using the MIXED procedure in the SAS statistical package (SAS 2009). The statistical model used was:

$Y i j \mathrm{k}=\mu+b i+\alpha \mathrm{j}+\beta \mathrm{k}+(\alpha \beta) \mathrm{jk}+\varepsilon i j \mathrm{k}$

where:

$Y i j k=$ experimental unit value in $i$ submitted block to $j$ variety and $k$ soil correction;

$\mu=$ overall average;

$b_{i}=$ random effect associated with $i$ block, $\mathrm{i}=1, \ldots, 4 \alpha j=$ associated fixed effect to $j$ variety, $\mathrm{j}=1$ e 2 ;

$\beta k=$ fixed effect of $k$ soil correction, $\mathrm{k}=1,2,3$;

$\alpha \beta i j=$ fixed effect of variation between $j$ variety with $k$ soil correction;

$\varepsilon i j k=$ random error associated with the experimental unit in $i$ block submitted a $j$ variety and $k$ soil correction.
When the effect of the model was significant, a pairwise comparison of the means for correction of soil acidity and genotype was performed by using Tukey's test. The level of significance of 0.05 for type I error was used for all analyses.

\section{RESULTS}

There was no significant interaction between the factors for any of the evaluated variables. There was also no significant effect of acidity correction or genotype on microbiota variables (LAB, syeasts and molds counts) (Table 3 ).

Silages from cassava cultivated with gypsum and lime+gypsum had significantly higher HMaxT compared to lime only (Table 3). The Caeté genotype showed significantly higher values of $\mathrm{pH}, \mathrm{DMR}$, MaxT and AMP than the Manteiguinha genotype ( $P<0.05$ for all variables). Manteiguinha, in turn, showed significantly higher AS than Caeté $(\mathrm{P}<0.01)$.

There was a significant effect of the correction of soil acidity on the concentration of EE and $\mathrm{N}-\mathrm{NH}_{3}(\mathrm{P}<0.01$; Table 4), while the other parameters of chemical composition did not vary significantly among treatments $(P>0.05)$. Silages of the Caeté genotype showed significantly higher concentrations of $\mathrm{DM}$ and NFC, and lower concentration of NDF $(\mathrm{P}<0.01)$ compared to Manteiguinha. The concentrations of $\mathrm{OM}$ and $\mathrm{CP}$ were not affected by genotype

\section{DISCUSSION}

The use of lime and gypsum alone or in combination usually increases growth and root production in cassava plants because of the soil acidity correction in the superficial soil layer $(0-20 \mathrm{~cm})$ by lime and the positive effects of neutralizing toxic $\mathrm{Al} 3+$ and providing sulfur $(\mathrm{S})$ and calcium $(\mathrm{Ca})$ by gypsum

Table 3. Microbial populations, fermentation characteristics and aerobic stability parameters of cassava (Manihot esculenta) root silage of two genotypes planted using three types of soil-acidity correction at the campus of Universidade Federal Rural da Amazônia, Belém (Pará state, Brazil). Values are the mean of eight (acidity correction) or 12 (genotype) samples.

\begin{tabular}{|c|c|c|c|c|c|c|c|c|c|}
\hline \multirow{2}{*}{ Parameter } & \multicolumn{3}{|c|}{ Soil acidity correction } & \multicolumn{2}{|c|}{ Genotype } & \multirow{2}{*}{ SEM } & \multicolumn{3}{|c|}{ P-value } \\
\hline & $\mathrm{L}$ & G & $\mathrm{L}+\mathrm{G}$ & $C$ & $M$ & & SC & GE & $\mathrm{SC} \times \mathrm{GE}$ \\
\hline Lactic acid bacteria $\left(\log \left(F U g^{-1}\right)\right.$ & 7.95 & 7.96 & 7.70 & 7.94 & 7.79 & 0.10 & 0.55 & 0.49 & 0.72 \\
\hline Yeasts $\left(\log C F U g^{-1}\right)$ & 3.28 & 3.13 & 3.00 & 3.19 & 3.08 & 0.05 & 0.16 & 0.39 & 0.41 \\
\hline Molds (log CFU g-1) & 3.17 & 3.10 & 3.04 & 3.14 & 3.07 & 0.03 & 0.17 & 0.13 & 0.20 \\
\hline $\mathrm{pH}$ & 4.13 & 4.25 & 4.28 & $4.35 \mathrm{a}$ & $4.10 \mathrm{~b}$ & 0.06 & 0.51 & 0.03 & 0.52 \\
\hline Dry matter recovery (\%) & 91.48 & 90.24 & 90.09 & $92.85 a$ & $88.37 b$ & 0.81 & 0.60 & $<0.01$ & 0.07 \\
\hline Effluent loss (kg t-1 FM) & 67.23 & 68.57 & 64.82 & 63.34 & 70.41 & 2.95 & 0.89 & 0.28 & 0.81 \\
\hline Aerobic stability (h) & 119.5 & 135.0 & 139.0 & $115.0 \mathrm{~b}$ & 147.0a & 4.98 & 0.09 & $<0.01$ & 0.98 \\
\hline Maximum temperature $\left({ }^{\circ} \mathrm{C}\right)$ & 30.48 & 28.63 & 29.56 & $29.77 a$ & $29.33 b$ & 0.27 & 0.68 & $<0.01$ & 0.68 \\
\hline Time to maximum temperature (h) & $142.5 b$ & $161.5 \mathrm{a}$ & $161.5 \mathrm{a}$ & 155.0 & 155.3 & 3.18 & 0.01 & 0.95 & 0.49 \\
\hline Temperature amplitude $\left({ }^{\circ} \mathrm{C}\right)$ & 3.56 & 3.77 & 3.33 & $4.48 \mathrm{a}$ & $2.63 b$ & 0.26 & 0.68 & $<0.01$ & 0.67 \\
\hline
\end{tabular}

CFU = colony forming units; FM = fresh matter; $L=$ lime; $G=$ gypsum; $L+G=$ lime+gypsum; $C=$ Caeté; $M=$ Manteiguinha; $S E M=$ standard error of the mean; SC = soil acidiy correction; $\mathrm{GE}=$ genotype; $\mathrm{SC} \times \mathrm{GE}=$ interaction between soil acidity correction and genotype. Means within group followed by different letters for a variable differ significantly by the Tukey test $(P<0.05)$. 
Table 4. Chemical composition of cassava (Manihot esculenta) root silage of two genotypes planted using three types of soil-acidity correction at the campus of Universidade Federal Rural da Amazônia, Belém (Pará state, Brazil). Values are the mean of eight (acidity correction) or 12 (genotype) samples.

\begin{tabular}{|c|c|c|c|c|c|c|c|c|c|}
\hline \multirow{2}{*}{ Parameter } & \multicolumn{3}{|c|}{ Soil acidity correction } & \multicolumn{2}{|c|}{ Genotype } & \multirow{2}{*}{ SEM } & \multicolumn{3}{|c|}{ P-value } \\
\hline & $\mathrm{L}$ & G & $\mathrm{L}+\mathrm{G}$ & C & M & & $\mathrm{SC}$ & GE & $\mathrm{SC} \times \mathrm{GE}$ \\
\hline Dry matter $\left(\mathrm{g} \mathrm{kg} \mathrm{FM}^{-1}\right)$ & 399.7 & 397.9 & 398.1 & $421.0 \mathrm{a}$ & $376.1 b$ & 11.25 & 0.98 & $<0.01$ & 0.61 \\
\hline Organic matter ( $\left.\mathrm{kg} \mathrm{DM}^{-1}\right)$ & 957.8 & 953.1 & 953.1 & 956.7 & 952.6 & 2.44 & 0.40 & 0.24 & 0.52 \\
\hline Crude protein ( $\mathrm{kg} \mathrm{DM}^{-1}$ ) & 22.1 & 22.1 & 21.8 & 21.6 & 22.3 & 0.24 & 0.95 & 0.46 & 0.63 \\
\hline Ether extract $\left(\mathrm{g} \mathrm{kg} \mathrm{DM}^{-1}\right)$ & $3.7 \mathrm{a}$ & $2.6 b$ & $3.5 \mathrm{ab}$ & 3.4 & 3.1 & 0.02 & $<0.01$ & 0.36 & 0.63 \\
\hline Neutral detergent fiber $\left(\mathrm{g} \mathrm{kg} \mathrm{DM}^{-1}\right)$ & 41.9 & 44.8 & 44.8 & $37.1 \mathrm{~b}$ & $50.6 a$ & 3.63 & 0.64 & $<0.01$ & 0.28 \\
\hline Non fibrous carbohydrates ( $\mathrm{g} \mathrm{kg} \mathrm{DM}{ }^{-1}$ ) & 890.2 & 878.8 & 877.0 & 893.0a & $871.0 \mathrm{~b}$ & 8.03 & 0.21 & $<0.01$ & 0.44 \\
\hline Ammonia nitrogen $\left(\mathrm{g} \mathrm{kg} \mathrm{TN}^{-1}\right)$ & $56.1 \mathrm{~b}$ & $59.7 \mathrm{ab}$ & $67.0 \mathrm{a}$ & 60.1 & 61.7 & 4.55 & 0.01 & 0.54 & 0.29 \\
\hline
\end{tabular}

$\mathrm{FM}=$ fresh matter; $\mathrm{DM}=$ dry matter; $\mathrm{TN}=$ total nitrogen; $\mathrm{L}=$ lime; $\mathrm{G}=$ gypsum; $\mathrm{L}+\mathrm{G}=\operatorname{lime}+$ gypsum; $\mathrm{C}=$ Caeté; $\mathrm{M}=$ Manteiguinha; $\mathrm{SEM}=$ standard error of the mean; $\mathrm{SC}=$ soil acidiy correction; $\mathrm{GE}=$ genotype; $\mathrm{SC} \times \mathrm{GE}=$ interaction between soil acidity correction and genotype. Means within group followed by different letters for a variable differ significantly by the Tukey test $(P<0.05)$.

(Zambrosi 2007; Vitti and Priori 2009). The correction of soil acidity with lime has been related to higher root production in cassava (Martins et al. 2018), while the application of gypsum promoted the increase in the dry matter of leaves in cassava genotypes, and the combination of lime and gypsum increased the root harvest rate (Nascimento et al. 2019). Such effects on productivity were not reflected in the characteristics of the silage in our study, including LAB, yeast and mold counts, as the fermentation process occurred within the expected for an adequate fermentation independently of the method of soil-acidity correction used. The values of LAB counts were higher than the average for tropical grass silage ( $4.73 \mathrm{cfu} \mathrm{g}^{-1}$ of fresh matter; Gandra et al. 2017) and for corn silage (4.59 cfu g $^{-1}$; Oliveira et al. 2017).

It is known that the activity of microorganisms influences the fermentation process during ensiling (Borreani et al. 2018). Although we did not analyze the microbiota during the early periods of the fermentation process, our silage-yeasts counts and DM-recovery values indicate that the yeast-growth rate was not high during the fermentation process, as our values for yeast count (3.0 to $3.3 \mathrm{cfu} \mathrm{g}^{-1}$ of fresh matter) are within the adequate range proposed by Pahlow et al. (2003) and Kung et al (2018). According to these authors, yeast counts above $5 \log \mathrm{cf} \mathrm{g}^{-1}$ indicate a high growth rate during fermentation that can affect the fermentation process by increasing DM losses, as observed in sugarcane silage (Ávila et al. 2010). The yeasts population in the silage is negatively correlated with aerobic stability (Schmidt and Kung Jr. 2010; Persson 2015) as they are usually the microorganisms that initiate the aerobic deterioration (Pahlow et al. 2003). The reason for this is that many yeasts are able to grow at $\mathrm{pH} 3.5$, well below the $\mathrm{pH}$ of most silages (Muck et al. 2010). The yeasts population at the opening of the silos did not seem to affect the aerobic stability of the cassava silages, since the values remained below $5 \log 10 \mathrm{cfu} \mathrm{g}^{-1}$. Silages that are actively deteriorating generally have values between 5.5 to $6.0 \log 10$ cfu g $^{-1}$ (Santos et al. 2014).
The $\mathrm{pH}$ values observed in our fermentation profiles were within the range of 3.8 to 4.2 observed for well fermented silages (McDonald et al. 1991; Kung Jr. et al. 2018), indicating that the fermentation profile of cassava roots in our study can be considered adequate. The difference observed between the two genotypes was statistically significant but falls within the range of values considered normal in the fermentation profile. In addition, the final $\mathrm{pH}$ of the silage (after at least 30 days) by itself does not provide enough information about the fermentation process, which should be evaluated by the $\mathrm{pH}$ of the first days of fermentation, when undesirable microorganisms are inhibited (Silva et al. 2018). Based on that, the silage that shows the fastest $\mathrm{pH}$ drop during the beginning of the fermentation will probably show higher DM recovery. This could explain the higher DM recovery observed for the Caeté genotype. The lower DM recovery observed for the Manteiguinha genotype may be related to different fermentation pathways, that produce acetic acid and ethanol, that increase $\mathrm{CO}_{2}$ production (Rooke and Hatfield, 2003)

Our effluent losses were high independently of the treatment, which was not expected for materials ensiled with $40 \% \mathrm{DM}$, as the cassava roots. However, these assumptions are based on the aerial parts of the plant, which have a high proportion of cell wall components (cellulose, hemicellulose and lignin) (Célino et al. 2014; Sorieul et al. 2016). After chopping, cassava roots form a dense mass from which a white liquid drips, which is reflected in the low concentration of NDF. It is known that the fiber has hygroscopic properties (Célino et al. 2014) and its low concentration could justify the high effluent production even in a material ensiled with 40\% DM.

The aerobic stability of our silages can be considered high in comparison with corn and sorghum silages. Corn silages are more prone to aerobic deterioration (Ranjit and Kung 2000), mainly due to the high production of lactic acid produced during fermentation, which is used as substrate by yeasts (Pahlow et al. 2003). Lactic acid, acetic acid and soluble sugars 
are main sources of energy for microorganisms involved in the deterioration of silage (Mcdonald et al. 1991). Therefore, silages with a low content of these components may show high aerobic stability. The adequate fermentation profile and high aerobic stability of our silage may also indicate that other chemical compounds or metabolites in the silage are affecting microbial populations and preserving the silage.

The high aerobic stability observed in our silages can be explained by their high moisture content, which can result in an acetic fermentation of the silage (Kung et al. 2018). High humidity silages (> 70\%) can be characterized by fermentation by heterolactic acid bacteria, enterobacteria, or even clostridia, which are microorganisms that produce acetic acid through their metabolism. (Mcdonald et al. 1991). This could explain the higher aerobic stability of the silage from the genotype with lower DMR, as a higher production of acetic acid would increase DM loss (Mcdonald et al. 1991). Aerobic stability could also result from yeast control by other compounds in the cassava, such as hydrocianidric acid or tannins, by inhibiting spoilage microorganisms such as yeasts (Nasir and Hamad 2014).

\section{CONCLUSIONS}

Cassava root silage from two genotypes (Caeté and Manteiguinha) cultivated with three types of soil-acidity correction showed an adequate fermentation profile, considerably high aerobic stability, and high effluent loss. The Caeté genotype had higher dry matter recovery, showing higher potential for silage production. Soil acidity correction with lime, gypsum or both in combination did not influence the characteristics of the silages in a meaningful way. Based on our results, the use of additives to improve the fermentation or aerobic stability is not needed for cassava root ensiling of these genotypes. However, due to the high production of effluents, the addition of a moisture-absorbent additive or the production of a total mixed ration during the ensiling process of cassava roots is likely necessary and should be formally tested.

\section{ACKNOWLEDGMENTS}

The authors thank the undergraduate and graduate students from Grupo de Estudos em Ruminantes e Forragicultura da Amazônia (GERFAM) at Universidade Federal Rural da Amazônia for the technical support; Coordenação de Aperfeiçoamento de Pessoal de Nível Superior - CAPES (Brazil); Programa Nacional de Cooperação Acadêmica (CAPES/Procad no71/2013) for the financial assistance; and Conselho Nacional de Desenvolvimento Tecnológico e Científico (CNPq, Brazil) for providing scholarships to the first and second authors.

\section{REFERENCES}

Ajibola, F.O.; Edema, M.O.; Oyewole, O.B. 2012. Enzymatic production of ethanol from cassava starch using two strains of Saccharomyces cerevisiae. Nigerian Food Journal, 30: 114-121.

Alvares, C.A.; Stape, J.L.; Sentelhas, P.C.; Gonçalves, J.L.M.; Sparovek, G. 2014. Köppen's climate classification map for Brazil. Meteorologische Zeitschrift, 22: 711-728.

AOAC. 1990. Official Methods of Analysis of the AOAC. 15th ed. Association of Official Analytical Chemists. Washington DC, 1230p.

AOCS. 2009. Official Methods and Recommended Practices of the AOCS. 6th ed. American Oil Chemists Society, Washington, $1200 \mathrm{p}$.

Ávila, C.L.S.; Martins, C.E.C.B.; Schwan, R.F. 2010. Identification and characterization of yeasts in sugarcane silages. Journal Applied of Microbiology, 109: 1677-1686.

Borreani, G.; Tabacco, E.; Schmidt, R.J.; Holmes, B.J.; Muck, R.E. 2018. Silage review: Factors affecting dry matter and quality losses in silages. Journal of Dairy Science, 101: 3952-3979.

Célino, A.; Fréour, S.; Jacquemin, F.; Casari, P. 2014. The hygroscopic behavior of plant fibers: a review. Frontiers in Chemistry, 1: 43. doi: $10.3389 /$ fchem. 2013.00043

CEPEA. 2020. Centro de Estudos Avançados em Economia Aplicada. Preços Agropecuários - Mandioca. (http://cepea.esalq.usp.br/br/ indicador/mandioca.aspx). Accessed on 10 May 2020.

Coelho, E.; Ballesteros, L.F.; Domingues, L.; Vilanova, M.; Teixeira, J.A. 2020. Production of a distilled spirit using cassava flour as raw material: chemical characterization and sensory profile. Molecules, 25: 3228. doi.org/10.3390/molecules25143228

Chisté, R. C.; Cohen, K.O.; Mathias, E.A.; Oliveira, S.S. 2010. Quantificação de cianeto total nas etapas de processamento das farinhas de mandioca dos grupos seca e d'água. Acta Amazonica, 40: 221-226.

Cravo, M.S,; Cardoso, E.M.R.; Botelho, S.M. 2010. Mandioca. In: Cravo M.S.; Viégas, I.J.M.; Brasil, E.C. (Ed.). Recomendaçôes de Adubação e Calagem para o Estado do Pará. Revised 1st ed. Embrapa, Belém, p.151-152.

Cravo, M.S.; Smyth, T.J.; Souza, B.D.L. 2016. Calagem e adubação para a cultura da mandioca. In: Modesto Júnior, M.S.; Alves, R.N.B. (Ed.). Cultura da Mandioca: Aspectos Socioeconômicos, Melhoramento Genético, Sistemas de Cultivo, Manejo de Pragas e Doenças e Agroindústria. Embrapa, Brasília, p.98-110.

Detmann, E.; Valadares Filho, S.C. 2010. On the estimation of non-fibrous carbohydrates in feeds and diets. Arquivo Brasileiro de Medicina Veterinária e Zootecnia, 62: 980-984.

Elias, M.; Muhlen, G.S.; Mckey, D.; Roa, A.C.; Tohme, J. 2004. Genetic diversity of traditional south american landraces of cassava (Manihot esculenta Crantz): an analysis using microsatellites. Economic Botany, 58: 242-256.

FAO. 2020. Food and Agriculture Organization of the United Nations. FAOSTAT (http://www.fao.org/faostat/en/?\#compare). Accessed on 27 Apr 2021.

Gandra, J.R.; Oliveira, E.R.; Goes, R.H.T.B.; Oliveira, K.M.P.; Takiya, C.S.; Del Valle, T.A.; Araki1, H.M.C.; Silveira, K.; Silva, D.; Pause, A.G.S. 2017. Microbial inoculant and an 
extract of Trichoderma longibrachiatum with xylanase activity effect on chemical composition, fermentative profile and aerobic stability of guinea grass (Panicum maximum Jacq.) silage. Journal of Animal and Feed Sciences, 26: 339-347.

IBGE. 2021. Instituto Brasileiro de Geografia e Estatística. Sidra: Sistema IBGE de Recuperação Automática. (https://sidra.ibge. gov.br/tabela/1618\#resultado). Accessed on 2 May 2021.

Jobim, C.C.; Nussio, L.G.; Reis, R.A.; Schmidt, P. 2007. Avanços metodológicos na avaliação da qualidade da forragem conservada. Revista Brasileira de Zootecnia, 36: 101-119.

Knop, M. 2011. Yeast cell morphology and sexual reproduction - A short overview and some considerations. Comptes Rendus Biologies, 334: 599-606.

Köppen, W. 1918. Klassification der Klimate nach Tempetarur, Niederschlag und Jahreslauf. Petermanns Geographische Mitteilungen, 64: 193-203.

Kung, L.; Shaver, R.D.; Grant, R.J.; Schmidt, R.J. 2018. Silage review: Interpretation of chemical, microbial and organoleptic components of silages. Journal of Dairy Science, 101: 4020-4033.

Loc, N.T.; Ogle, R.B.; Preston, T.R. 1997. Cassava root silage for crossbred pigs under village conditions in Central Vietnam. Livestock Research for Rural Development, 9: \#14. http://www. lrrd.org/lrrd9/2/loc922.htm

Martins, J.S.; Parreira, M.C.; Ribeiro, R.C.; Silva, E.M. 2018. Calcário e sua influência no cultivo de mandioca na Amazônia Tocantina. Revista Brasileira de Agropecuária Sustentável, 8: 17-23.

Mcdonald, P.; Henderson, A.R; Heron, S. 1991. The Biochemistry of Silage. 2nd ed. Chalcombe Publications, Marlow, 340p.

Muck, R.E. 2010. Silage microbiology and its control through additives. Revista Brasileira de Zootecnia, 39: 183-191.

Nascimento, I.S.B.; Barradas, J.O.; Araújo, L.B.; Pacheco, M.J.B.; Viana, T.C.; Jesus, A.M.B.S.; Galvão, J.R. 2019. Variáveis fitométricas de macaxeira (Manihot esculenta Crantz) em resposta à aplicação de calagem e gesso agrícola. Sustinere, 7: 381-393.

Nasir, H.A.B.; Hamad, N.A.B. 2014. Effect of tannic acid on growth and acid production of candida albicans. 2014. Pakistan Oral \& Dental Journal, 34: 405-408.

O'Kiely, P. 1993. Influence of a partially neutralized blende of aliphatic organic acids on fermentation, effluent production and aerobic stability of autumm grass silage. Journal of Agricultural and Food Research, 32: 13-26.

Oliveira, L.I.; Lima, L.M.; Casagrande, D.R.; Lara, M.A.S.; Bernardes, T.F. 2017. Nutritive value of corn silage from intensive dairy farms in Brazil. Brazilian Journal of animal Science, 46: 494-501.

Pahlow, G.; Muck, R.E.; Driehuis, F.; Oude Elferink, S.J.W.H.; Spoelstra, S.F. 2003. Microbiology of ensiling. In: Buxton, D.R.; Muck, R.E.; Harrison, H.J. (Ed.). Silage Science and Technology .v.42, American Society of Agronomy, Madison, p.31-93.

Persson, A. 2015. Yeast in forage crops and silage aerobic stability at 15 Swedish dairy farms. Master's dissertation, Swedish University of Agricultural Sciences, Sweden, 37p. https://stud.epsilon.slu. se/7780/17/persson_a_150421.pdf

Raij, B.V. 1991. Fertilidade do Solo e Adubação. 1st ed. Ceres/Potafós, Piracicaba, 343p.
Ranjit, N.K.; Kung Jr., L. 2000. The effect of Lactobacillus buchneri, Lactobacillus plantarum, or a chemical preservative on the fermentation and aerobic stability of corn silage. Journal of Dairy Science, 83: 526- 535.

Rooke, J. A.; Hatfield, R.D. 2003. Biochemistry of ensiling. In: Buxton, D.R.; Muck, R.E.; Harrison, H.J. (Ed.). Silage Science and Technology, v.42. American Society of Agronomy, Madison. p.95-139

Santos, H.G.; Jacomine, P.K.T.; Anjos, L.H.C.; Oliveira, V.A.; Oliveira, J.B.; Coelho, M.R.; Lumbreras, J.F; Cunha, T.J.F. 2013. Sistema Brasileiro de Classificação de Solos. 3rd. ed. Embrapa Solos, Rio de Janeiro, 335p.

Santos, M.A.S.; Santana, A.C. 2012. Caracterização socioeconômica da produção e comercializaçáo de farinha de mandioca no município de portel, arquipélago do marajó, estado do pará. Revista Verde de Agroecologia e Desenvolvimento Sustentável, 7: 73-86.

Santos, M.C.; Lock, A.L.; Mechor, G.D.; Kung Jr, L. 2014. Effects of a spoilage yeast from silage on in vitro ruminal fermentation. Journal of Dairy Science, 98: 2603-2610.

Saree, S.; Bunchasak, C.; Rakangtong, C.; Sakdee, J.; Krutthai, N.; Poeikhampha, T. 2017. Comparative effects of corn-based diet and phase-fed cassava-based diet on growth rate, carcass characteristics and lipid profile of meat-type ducks. AsianAustralasian Journal of Animal Science, 30: 843-848.

SAS. 2009. Statistical Analysis Sistem. SAS/STAT 9.2 User's Guide. SAS Institute Inc, Cary NC.

Schmidt, R.J.; Kung Jr., L. 2010. The effects of Lactobacillus buchneri with or without a homolactic bacterium on the fermentation and aerobic stability of corn silages made at different locations. Journal of Dairy Science, 93: 1616-1624.

Silva, L.D.; Pereira, O.G.; Silva, T.C.; Leandro, E.S.; Paula, R.A.; Santos, S.A.; Ribeiro, K.G.; Valadares Filho, S.C. 2018. Effects of Lactobacillus buchneri isolated from tropical maize silage on fermentation and aerobic stability of maize and sugarcane silages. Grass and Forage Science, 73: 660-670.

Silva, T.C; Moura, Z.A.; Santos, E.M.; Dórea, J.R.R.; Dantas, P.A.S.; Pereira, O.G. 2010. Evaluation of elephant grass silage with the addition of cassava scrapings. Revista Brasileira de Zootecnia, 39: 2611-2616.

Soares, M.R.; Alleoni, L.R.F.; Vidal-Torrado, P.; Cooper, M. 2005. Mineralogy and ion exchange properties of the particle size fractions of some Brazilian soils in tropical humid áreas. Geoderma, 125: 355-367.

Sorieul, M.; Dickson, A.; Hill, S.J.; Pearson, H. 2016. Plant fibre: molecular structure and biomechanical properties of a complex living material, influencing its deconstruction towards a biobased composite. Materials, 9: 618. doi: 10.3390/ma9080618

Sousa, D.M.G.; Miranda, L.N.; Oliveira, S.A. 2007. Acidez do solo e sua correção. In: Novais, R.F.; Alvarez, V.V.H.; Barros, N.F.; Fontes, R.L.F.; Cantarutti, R.B.; Lima, J.C. (Ed.). Fertilidade do Solo. SBCS, Viçosa, p.205-274.

Sudarman, A.; Hayashida, M.; Puspitaning, I.R.; Jayanegara, A.H.; Shiwachi, H. 2016. The use of cassava leaf silage as a substitute for concentrate feed in sheep. Tropical Animal Health and Production, 48: 1509-1512. 
Supapong, C.; Cherdthong, A.; Waanapat, M. 2019. Effects of sulfur levels in fermented total mixed ration containing fresh cassava root on feed utilization, rumen characteristics, microbial protein synthesis, and blood metabolites in Thai native beef cattle. Animals, 9: 261. doi.org/10.3390/ani9050261

Vieira, P.A.S.; Azevêdo, J.A.G.; da Silva, F.F.; Pereira, L.G.R.; Neves, A.L.A.; dos Santos, A.B.; Souza, L.L.; dos Santos, R.D. 2017. Parâmetros ruminais e balanço de nitrogênio em bovinos alimentados com silagem da raiz de mandioca. Pesquisa Veterinária Brasileira, 37: 883-890.
Vitti, G.C.; Priori, J.C. 2009. Calcário e gesso: os corretivos essenciais ao plantio direto. Revista Visão Agrícola, 9: 30-34.

Zambrosi, F.C.B.; Alleoni, L.R.F.; Caires, E.F. 2007. Aplicação de gesso agrícola e especiação iônica da solução de um Latossolo sob sistema de plantio direto. Revista Ciência Rural, 37: 110-117.

RECEIVED: 20/10/2020

ACCEPTED: 26/04/2021

ASSOCIATE EDITOR: Antonio R. Fernandes 